\title{
Г.А. Шаньгинова
}

\section{ЦЕНТРЫ ПРАВОВОЙ И ДЕЛОВОЙ ИНФОРМАЦИИ ПУБЛИЧНЫХ БИБЛИОТЕК (НА ПРИМЕРЕ МУХОРШИБИРСКОЙ ЦЕНТРАЛИЗОВАННОЙ БИБЛИОТЕЧНОЙ СИСТЕМЫ РЕСПУБЛИКИ БУРЯТИЯ)}

\begin{abstract}
В статье раскрывается деятельность публичных библиотек по обеспечению правовой информацией жителей села на примере Центра правовой и деловой информации МБУК «Мухоршибирская ЦБС» Республики Бурятия. Дана характеристика ресурсов документного фонда - онлайновым и оффлайновым. Освещаются направления работы Центра - консалтинг, информационное обеспечение законодательных и исполнительных структур различных уровней, повышение гражданско-правовой культуры избирателей, сотрудничество со СМИ, выполнение справок.

Ключевые слова: правовая информация, Центр правовой и деловой информации, документный фонд, пользователи, справки.
\end{abstract}

В условиях формирования правового общества особая роль отводится правовой культуре всех категорий населения. Значительный вклад в создание единого информационного пространства вносят российские библиотеки, с начала 1990-х гг. занявшие нишу правового обеспечения граждан. В регионах эта деятельность стала осуществляться значительно позднее. Так, Центр правовой информации Национальной библиотеки Республики Бурятия был создан в 2001 г. Главной задачей Центра является организация свободного доступа граждан к нормативно-правовым документам. В работе активно используются информационно-поисковые системы КонсультантПлюс, ГАРАНТ и документный фонд справочного и энциклопедического характера - кодексы, законы и комментарии к ним; сборники официальных документов Российской Федерации и Республики Бурятия, документы международного и зарубежного права; периодические издания по вопросам государства и права [1].

В одном из районов Бурятии на базе МБУК Мухоршибирской централизованной библиотечной системы с 2003 г. функционирует Центр правовой и деловой информации [2]. Основные направления деятельности Центра - предоставление населению оперативного доступа к правовой и социально значимой информации, информационная поддержка программ и проектов социально-экономического и культурного развития района. Безусловно, успешное решение этих задач полностью зависит от документного фонда, который включает справочные правовые системы ИПС «Законодательство России» Спецсвязи России, КонсультантПлюс, ГАРАНТ, ресурсы в Интернете, базы данных, различную информацию в виде оффлайновых электронных документов (CD-ROM, DVD), печатные издания. Центр правовой и деловой информации приобретает разнообразные электронные документы: «Сборник 
регионального законодательства» («Собрание нормативных актов 40 субъектов РФ»), «Образцы правовых (деловых) документов», «Большая российская юридическая энциклопедия», «Доступ граждан к правовой информации» (материалы международных круглых столов), «Ваше право» и др.

Среди проблем формирования фонда правовой информации отмечается нерегулярное поступление, что отражается на полноте документного собрания. Частично решить проблему помог НФ «Пушкинская библиотека», благодаря которому библиотека в достаточной мере пополнила свои фонды. В значительной степени восполнению лакун способствует подписка на периодические издания: «Российский адвокат», «Российская юстиция», «Юридический консультант», «Государство и право», «Практика местного самоуправления».

В Центре проводится консалтинговая работа. Так, запросы правовой тематики выполняются библиографом и специалистом-юристом. Основной круг вопросов, интересующий пользователей, заключается в поиске контактных данных, графика работы и условий приема специалистов социальных и юридических служб Мухоршибири, готовых оказать необходимую помощь. Огромный плюс для пользователей в том, что юридические консультации в Центре правовой и деловой информации осуществляются бесплатно. Анализ справок показал разнообразие контингента пользователей, обращающихся за правовой информацией, - государственные служащие, преподаватели школ и техникума, предприниматели, студенты, пенсионеры, безработные, инвалиды и пр. В целом ежегодно услугами Центра пользуются примерно 100-150 человек.

Другое направление деятельности Центра правовой и деловой информации - информационное обеспечение законодательных и исполнительных структур различных уровней по вопросам экономического, политического, социального развития района. К таковым структурам относятся: аппарат главы администрации, управление культуры, областная избирательная комиссия, отдел по социальной политике, информационно-аналитический отдел.

Тематические запросы данной категории пользователей можно сгруппировать в следующие: демографическая ситуация в регионе; привлечение инвестиций в экономику и социальную сферу; развитие жилищного ипотечного кредитования; социальная поддержка малообеспеченного населения; кадровая политика в органах государственной власти и местного самоуправления; инновационные формы и методы работы органов власти с населением, правовые основы деятельности муниципальных образований; повышение правовой культуры избирателей; деятельность учреждений культуры в новых условиях.

Информирование специалистов администрации происходит по системам ИРИ (избирательное распространение информации), ДОР (дифференцированное обслуживание руководителей), в режиме «Вопрос - ответ» и на опережающий спрос. с учетом занятости этих пользователей правовая информация может быть представлена по электронной почте, с помощью телефонной связи, по факсу. Пользуются популярностью и печатные способы предоставления информации - дайджесты, экспресс и обзорная информация, прессрелизы, библиографические списки. 
Помимо местной администрации, Центр правовой и деловой информации оказывает информационные услуги в области права различным организациям и учреждениям посредством информационных часов, пятиминуток, Дней информации.

Следующее направление деятельности Центра правовой и деловой информации - повышение гражданско-правовой культуры избирателей. Данная работа осуществляется в тесном сотрудничестве с районной администрацией - МБУК «МЦБС» включена в состав Координационного совета по повышению правовой культуры населения. Особое внимание уделяется повышению гражданского самосознания и самоопределения, что является задачей Молодежной школы права. Основное направление школы - формирование у нового поколения правовых знаний.

К участию в Молодежной школе права были привлечены учащиеся общеобразовательной школы, начального профессионального образования. В преподавании ставился акцент на сущности, назначении и принципах выборов, избирательной кампании и избирательной процедуре, о современных избирательных системах, избирательной системе России, истории президентской власти и т. д. Как показал опыт, интерактивные формы наиболее востребованы учащимися. Например, занятие в форме игры по теме «Выбираем главу Мухоршибири». Творческая работа участников реализовывалась посредством выдвижения кандидатур, разработки программы развития, агитационной работы. Впоследствии избирательная комиссия подводила итоги голосования, определяя лучшего на пост главы администрации района.

Не менее интересной для учащихся оказалась игра по другой теме: «В мире избирательного права», в ходе которой активно использовалась правовая информация.

Примеров функционирования подобных правовых школ для молодёжи много. В частности, на базе Республиканской детско-юношеской библиотеки Республики Бурятия работала Молодежная школа права «Гражданин XXI века». Одна из задач Молодежной школы права - помощь пользователям в приобретении навыков работы с правовыми документами, поэтому для них организуются практикумы и обучающие семинары. Представляют интерес мероприятия в рамках городского фестиваля молодого избирателя «Выбор за нами!» - встречи с депутатами, «Неделя правовых знаний», выставкипросмотры «Молодому избирателю», «Источники правовых знаний», «Организация правового образования», учебный семинар «Электронные правовые технологии» и многое другое [3].

Широкому охвату населения правовой информацией способствует сотрудничество библиотеки с местными средствами массовой информации - циклы телевизионных передач, публикации в газете «Земля Мухоршибирская».

В целях выявления отношения пользователей к правовому информированию библиотекой проводилось исследование для различных групп населения: молодежи, пенсионеров, безработных, работников различных организаций и учреждений. На основании результатов анкетирования значительная часть опрошенных (75\%) обращается к правовой литературе. Все пользователи позитивно оценивают роль библиотеки в этом процессе и работу Общественной приёмной, функционирующей при Центре. 
В информационном обеспечении правового характера большое внимание уделяется социально незащищённым гражданам - пенсионерам, инвалидам, безработным, малоимущим. Как свидетельствуют результаты исследования, отмечается значительный рост запросов от данных категорий населения. Так, для них проводятся правовые уроки, обзоры, информационные часы - по трудоустройству молодежи, по жилищному, трудовому законодательству; выпускается разнообразная издательская продукция: «Что такое соцпакет?»; «Как получить пособие по безработице?» и др. В последние годы происходит увеличение вопросов пользователей по изменениям и дополнениям в пенсионном законодательстве, изменений в налогообложении частных предпринимателей.

Обобщая вышесказанное, отметим, что сегодня услуги Центра пользуются спросом среди различных категорий населения. Вероятно, высокая его востребованность связана с предоставлением той информации, которая помогает адаптироваться в современной жизни, решить возникшие проблемы, получить не только необходимые сведения, но и социально-правовую помощь.

Как показывают исследования автора и научные изыскания студентов в рамках выпускных квалификационных работ, деятельность различных центров правовой информации и библиотек в целом вносит значительный вклад в формирование правовой культуры населения, и молодёжи в частности.

\section{Лumepamypa}

1. Национальная библиотека Республики Бурятия : официальный сайт [Электронный реcypc]. URL: http://nbrb.ru/newsite/?page_id=1261 (дата обращения: 15.05.2015).

2. Мухоршибирская централизованная библиотечная система : официальный сайт [Электронный ресурс]. URL: http://muhorsh.burnet.ru/index.html (дата обращения: 15.05.2015).

3. Шаньгинова Г.А. Изучение информационных потребностей юношества // Библиотечноинформационная деятельность : проблемы и перспективы : сб. науч. тр. Улан-Удэ, 2008. С. 108112 .

Shanginova Galina A. East-Siberian State Academy of Culture and Arts (Ulan-Ude, Russian Federation). E-mail: gala_shanginova@mail.ru. DOI 10.17223/22220836/19/19

THE CENTERS OF LEGAL AND BUSINESS INFORMATION IN PUBLIC LIBRARIES (FOR EXAMPLE OF THE MUHORSHIBIRSKI CENTRALIZED LIBRARY SYSTEM OF THE REPUBLIC OF BURYATIA)

Key words: legal information, Centre for legal and business information, document fund, users, reference.

In the conditions of formation of the legal community have a special role in the legal culture of all categories of the population. A significant contribution to the creation of a single information space make Russian libraries, from the beginning of 1990-ies which occupied the niche of the legal security of citizens. In the regions this activity was carried out much later. The centre for legal and business information MUK Muhorshibirskii centralized library system of the Republic of Buryatia is responsible for: providing to the public prompt access to legal and socially important information, information support programs and projects for socio-economic and cultural development of the area. Document Fund includes a reference to the legal system of the IRS «Legislation of Russia» Post of Russia «Consultant Plus», «GARANT», Internet resources, databases, and various information in the form of offline electronic documents (CD-ROM, DVD), periodicals. The centre for legal and business information acquires a variety of electronic documents: «a Collection of regional legislation» («Collection of normative acts of the 40 subjects of the Russian Federation»), «Samples of legal (business) documents», «Big Russian legal encyclopedia», «the Access of citizens to legal information» (materials of international round tables), «Your right», etc.

Among the problems of formation of Fund of legal information notes irregular payment that impact on the completeness of document Assembly. To partially solve the difficulties in selection helped 
the NF «Pushkin library», thanks to which the library is sufficiently replenish their funds. Largely to fill gaps promotes subscription to periodicals: «Russian lawyer», «Russian justice», «Legal adviser», «State and law», «the Practice of local government». The main activities of the Centre for legal and business information and consulting work, information provision legislative and Executive structures at various levels on issues of economic, political and social development of the area, improving civil legal culture of voters (including youth).

In summary, we note that today the Center's services are in demand among different categories of the population. Probably, the high demand associated with providing the information that helps it to adapt to modern life, to solve problems, to obtain not only the necessary information, but social and legal assistance.

\section{References}

1. The National Library of the Republic of Buryatia. (n.d.) Natsional'naya biblioteka Respubliki Buryatiya: ofitsial'nyy sayt [The National Library of the Republic of Buryatia: the official website]. [Online] Available from: http://nbrb.ru/newsite/?page_id=1261. (Accessed: 15th May 2015).

2. Mukhorshibirsk Centralized Library System. (n.d.) Mukhorshibirskaya tsentralizovannaya bibliotechnaya sistema: ofitsial'nyy sayt [Mukhorshibirsk Centralized Library System: the official website]. [Online] Available from: http://muhorsh.burnet.ru/index.html. (Accessed: 15th May 2015).

3. Shan'ginova, G.A. (2008) Izuchenie informatsionnykh potrebnostey yunoshestva [A study of the information needs of the youth]. In: Bibliotechno-informatsionnaya deyatel'nost': problemy i perspektivy [Library and Information Work: Challenges and Prospects]. Ulan-Ude. pp. 108-112. 